$\begin{array}{lll}\text { Polonia } & \text { https://doi.org/10.36228/PJ.9/2019.8 } & \text { nr } 9 / 2019\end{array}$

Piotr Czech

Państwowa Wyższa Szkoła Zawodowa w Oświęcimiu

ORCID: https://orcid.org/0000-0002-3543-0954

\title{
WARTOŚĆ PRACY ZAWODOWEJ W PERSPEKTYWIE KLIENTA POMOCY SPOŁECZNEJ - ŚLĄSKIE DYWAGACJE
}

\section{VALUE OF PROFESSIONAL WORK IN THE PERSPECTIVE OF A SOCIAL WELFARE CLIENT - SILESIAN DIGRESSIONS}

\begin{abstract}
ABSTRAKT
$\mathrm{Na}$ początku artykułu przedstawia się zagadnienie pojęcia wartości, z punktu widzenia filozoficznego. Wśród świata wartości, szczególne miejsce przypada niezbywalnej godności ludzkiej. W kolejnym etapie przechodzi się do szczegółowej analizy jednej z ważniejszych wartości, a mianowicie ludzkiej pracy. Rozważając wartość pracy ludzkiej, pragnie się ją śledzić poprzez śląskie doświadczenia.
\end{abstract}

Słowa kluczowe: człowiek, ethos, praca, Śląsk, wartość

\begin{abstract}
At the beginning of the article, the concept of value is presented from the philosophical point of view. Among the world of values, special place belongs to inalienable human dignity. In the next stage, one proceeds to a detailed analysis of one
\end{abstract}


of the most important values, namely human work. Considering the value of human work, inevitable leads to observations through Silesian experience.

Keywords: man, ethos, work, Silesia, value

„Wolność stanowi dla każdego człowieka jednocześnie dar i zadanie"1. Formułowanie pytania o wartość jest pytaniem trudnym nie tylko z filozoficznego punktu widzenia, bo to pytanie o to: do czego dążymy, czego pragniemy, co robimy, jak powinniśmy postępować. Jednocześnie jest to pytanie o człowieka i o istotę człowieczeństwa. Wartości to w naszym życiu swoisty drogowskaz: do czego dążyć, czego poszukiwać, co robić, jak postępować, co uznajemy za dobre, a co za złe. Określenia dobry i zły stanowią podstawę naszych wartościowań2. „Wartość to wzorzec domagający się urzeczywistnienia w ludzkim czynie”3. Jednocześnie zdecydowanie łatwiej wymienić wartości niż je zdefiniować. „Zależnie od dyscypliny naukowej ukazywane są różne ujęcia wartości

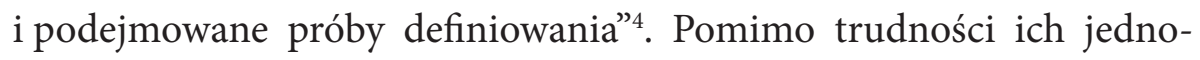
znacznego zdefiniowania stanowią wzorce - normy zachowania, postępowania zarówno dla jednostki, grupy czy całej społeczności. O ile jednostka może nie utożsamiać się ze wszystkimi „powszechnymi” war-

${ }^{1}$ M. Drzewiecki, Wychowanie $w$ dobie ponowoczesności. Wydawnictwo JEDNOŚĆ, Kielce 2002, s. 127.

2 Por. Jan Paweł II, Aby wychowanek nauczył sie „być, a nie tylko „wiedzieć”, w: Rodzina w nauczaniu Jana Pawła II. Antologia wypowiedzi, J. Żukowicz (red.), Kraków 1990, s. 192-193.

3 A. Szołtysek, Filozofia pedagogiki. Podstawy edukacji: teoria - metodyka praktyka, Wydawnictwo IMPULS, Katowice 2003, s. 285.

${ }^{4} \mathrm{~K}$. Chałas, Wychowanie ku wartościom. Elementy teorii i praktyki. Godność, wolność, odpowiedzialność, tolerancja, t. 1, Wydawnictwo JEDNOŚĆ, Lublin-Kielce 2003, s. 16. 
tościami i pozostaje społecznie akceptowana, to dla społeczności wartości odgrywają istotną rolę, ponieważ m. in.: utrzymują ład, wyznaczają kierunki działania, stanowią spoiwo społeczności. Jednocześnie zróżnicowanie wartości może wywoływać konflikty, dlatego też niezwykle ważne jest wypracowanie wspólnych, względnie jednolitych wartości akceptowanych przez jednostkę i społeczność.

Wartości zostają poddane weryfikacji i zmieniają się, są „dostosowywane" do realiów życia, jednak istnieją te nadrzędne, szczególnie ważne, które wyznaczają zachowania człowieka, w głównej mierze są to wartości takie jak: wolność, godność. „Wartości to, co ze względu na swoją naturę odpowiada człowiekowi jako człowiekowi...”. „Wartości podstawowe w rozumieniu myśli społecznej nadają sens i swoistą tożsamość danej społeczności. Wyznaczają kierunek działań, odnoszą się do zinterioryzowanych standardów zachowań nabywanych w procesie socjalizacji dzięki określonym warunkom społeczno - kulturowym"6.

Wartości są bardziej jakościami, które czynią rzeczy bardziej wartościowymi niż samymi rzeczami. To jakości nadają rzeczom określone znaczenia. „Łącznikiem człowieka ze światem wartości są jego zdolności poznawcze i wolitywne. Wartość jest tym, co w sposób najbardziej pełny umożliwia rozwijanie tych zdolności. Czyni także życie człowieka pełnym, daje mu nie tylko poczucie, ale i również niedostępne w inny sposób spełnienie. Zatem realizacja wartości wiąże się ze szczęściem rozumianym jako uporządkowanie swoich pragnień, relacji wobec innych ludzi oraz otoczenia, aby można było cieszyć się w sposób możliwie niezmącony z poznawania świata, $\mathrm{z}$ kontaktów z innymi osobami oraz $\mathrm{z}$ realizacji własnych życiowych celów i osiąganych sukcesów”7. „Wol-

${ }^{5}$ G. Grzybek, Etyka rozwoju a wychowanie. Wydawnictwo Uniwersytetu Rzeszowskiego. Rzeszów 2010. s. 25

${ }^{6}$ Tamże. s. 26

${ }^{7}$ G. Grzybek, Praca socjalna w założeniach „etyki rozwoju”, [w:] Stala J., (red.) Przestrzenie pracy socjalnej, Wydawnictwo Biblos, Tarnów 2010. s. 71. 
ność, jako wolna wola, jako możliwość autonomicznego podejmowania decyzji, jest elementem ludzkiej natury. Jest też wielką aspiracją każdego człowieka"".

Człowiek jako jednostka rozumna istnieje w sobie i dla siebie, jest bytem niezależnym, autonomicznym, suwerennym podmiotem działania stanowiącym o sobie. Poprzez akty wyboru celów, sposobów i warunków działania wzbogaca się wewnętrznie, ciągle dążąc do coraz doskonalszego wymiaru własnej podmiotowości. Tym samym człowiek wybiera wartości. Proces ubogacania swojej osobowości w zasadniczym stopniu jest procesem ciągłego wyboru wartości. Trwa on przez całe życie człowieka. To zaś, na ile człowiek jest wiernym wobec wybranych wartości, jaka jest ich treść i struktura, określa wymiary jego człowieczeństwa9. Zdefiniowanie wartości nie jest rzeczą prostą. Według W. Tatarkiewicza „zdefiniowanie wartości jest trudne, jeśli w ogóle możliwe.... To, co wygląda na definicję wartości, jest raczej zastąpieniem wyrazu przez inny wyraz mniej więcej to samo znaczący albo jest jego omówieniem” ${ }^{10}$. Najczęściej wartość „określa się tym terminem:

- to, co cenne,

- co zgodne z naturą (działające lub wartościujące),

- czego chcemy, cel, przedmiot (aktualnego lub potencjalnego) dążenia,

- czego pożądamy,

- co zaspokaja potrzeby, zainteresowania,

- co dostarcza zadowolenia, przyjemności,

- co powinno być,

${ }^{8}$ M. Drzewiecki, Wychowanie w dobie ponowoczesności, dz. cyt., s. 128.

9 Por. W. Furmanek, Człowiek, człowieczeństwo, wychowanie, Wydawnictwo Uniwersytetu Rzeszowskiego, Rzeszów 1995, s. 34.

${ }_{10}$ W. Tatarkiewicz, Paregra, Państwowe Wydawnictwa Naukowe, Warszawa 1978, s. 61. 
- co lepiej, żeby było niż nie było,

- co zobowiązuje, apeluje do odbiorcy,

- co domaga się istnienia (realizacji)"11.

„Okazuje się jednak, że wrodzone możliwości oraz aspiracje, by być wolnym to jeszcze za mało, aby rzeczywiście żyć w wolności” ${ }^{12}$. W naukach Jana Pawła II największą wartość stanowi człowiek w swoim człowieczeństwie. „Konkretny człowiek - osoba jest powiązana z określonym kręgiem kultury, narodem, wyznaniem, jest członkiem rodziny, państwa, wykonuje jakiś zawód itd. To właśnie osoba posiada swą godność, która jest wartością najwyższą, bezwzględną w świecie bytów stworzonych. Duchowość osoby stanowi dla niej wyzwanie do ciągłego trudu samodoskonalenia się, upodabniania się do doskonałości Stwórcy” ${ }^{13}$. Jednocześnie „kształtować osobę ze względu na jej najwyższy cel i najwznioślejsze dążenia społeczeństwa, w których będzie ona żyła jako człowiek dorosły, harmonijnie rozwijać wszystkie jej zdolności, zdolność do wysiłku i poczucie odpowiedzialności, pomóc jej w osiągnięciu panowania nad własną wolnością"14.

Tym samym „wartości są podstawą, która nie tylko decyduje o życiu, ale także określa linie postępowania i strategie, które budują życie w społeczeństwie. Nie można oddzielać od siebie wartości osobistych i wartości społecznych"15. Cała nauka dotycząca budowania cywilizacji miłości, równieżwybór wartościduchowychi ludzkichzwiązanychz „byciembar-

${ }^{11}$ A. Stępień, Wstęp do filozofii, Wydawnictwo Towarzystwo Naukowe Katolickiego Uniwersytetu Lubelskiego, Lublin 2001.

${ }^{12}$ M. Drzewiecki, Wychowanie w dobie ponowoczesności, dz. cyt., s. 128.

${ }^{13}$ F. Adamski, Wychowanie na rozdrożu: personalistyczna filozofia wychowania, Wydawnictwo Uniwersytetu Jagiellońskiego, Kraków 1999, s. 196.

${ }^{14}$ T. Styczeń, Antropologia Karola Wojtyły, [w:] „Osoba i czyn” oraz inne studia antropologiczne, Seria: Człowiek i Moralność, t. 4, red. T. Styczeń, W. Chudy, Lublin, s. 502 .

${ }^{15}$ F. Adamski, Wychowanie na rozdrożu..., dz. cyt., s. 196. 
dziej", wymagają dużego samozaparcia i pracy nad sobą ... nie można żyć w niekonsekwencji: wymagać od innych i od społeczeństwa, a samemu prowadzić życie tak, jakby wszystko w nim było dozwolone"16.

$\mathrm{Z}$ wielu przywołanych wartości, tych najważniejszych są również jeszcze wartości bardziej istotne z perspektywy jednostki, ale zarazem ważne dla całego społeczeństwa. Jedną $\mathrm{z}$ takich wartości jest ludzka praca, która powinna zapewnić jednostce środki na funkcjonowanie i umożliwiać zaspakajanie potrzeb, jednocześnie społeczności m.in.: pozwala rozwijać się, budować sprzyjające warunki egzystencji. „Praca, zbiorowa lub jednostkowa działalność, której celem jest uzyskanie jakiegoś wytworu materialnego bądź niematerialnego. Ze względu na znaczenie tego wytworu dla jednostki czy dla społeczeństwa oraz na niezbędne wydatkowanie sił, procesowi pracy na ogół towarzyszy przekonanie o jej pożytku, ale zarazem przymus wewnętrzny, tj. narzucony sobie przez jednostkę lub zewnętrzny, tj. narzucony przez społeczeństwo warunki życia zbiorowego"17.

„Od początku istnienia człowieka nierozłącznym elementem jego egzystencji jest praca. Towarzyszy ona każdej zbiorowości od wspólnie podejmowanych wysiłków pozyskania żywności dla własnego plemienia, poprzez własnoręczne wykonywanie przedmiotów na potrzeby własne lub na wymianę, po odrabianie pańszczyzny czy pracę zarobkową. Przez wieki wykonywanie pracy i jej efekty nabierały rozmaitego znaczenia i przedstawiały różną wartość. Odmienne znaczenie miała praca wykonywana przez niewolników, czym innym było odrabianie pańszczyzny. Sytuacja uległa zmianie wokresie reformacji i rozwoju kapitalizmu, kiedy to powstało zapotrzebowanie na pracowników, którzy posiedli umiejętność pracy w przemyśle. Za najbardziej uprzemysłowiony ob-

${ }^{16}$ Jan Paweł II, Aby wychowanek nauczyt się „być”, a nie tylko „wiedzieć”, dz. cyt., s. $192-193$.

${ }_{17}$ W. Okoń, Nowy słownik pedagogiczny, Wyd. Akademickie Żak, Warszawa 2007, s. 327. 
szar naszego kraju uznawany był Śląsk, na jego terenie praca stała się trwałym i tożsamym elementem życia, nigdy też nie miała negatywnych zabarwień. „Na ziemiach polskich kapitalizm najsilniej utrwalił się na Śląsku. Praca w przemyśle wymagała innego rodzaju pracy, a wraz $\mathrm{z}$ nią innego etosu"18.

Druga połowa XIX i początek XX wieku to czas formułowania się śląskiego wzorca pracy, przede wszystkim w przemyśle wydobywczym, gdzie jednocześnie stawała się jedną z największych wartości. Na poszanowanie pracy niewątpliwy wpływ miała niemiecka rzetelność, solidność i dyscyplina. „Kultura pracy była przyjmowana wraz z całością kultury niemieckiej i często było to związane z podziwem dla jej poziomu cywilizacyjnego" ${ }^{19}$. Niemieckie wzorce kulturowe oceniały wartość człowieka przez pryzmat wykonywanej pracy, posiadanych kwalifikacji zawodowych oraz zarobionych pieniędzy, a wszelkiego rodzaju inne formy uzyskiwania środków finansowych spotykały się z nieżyczliwością czy wręcz pogardą. Znaczący wpływ na cechy robotników, takie jak: pracowitość, uczciwość, dyscyplina, posłuszeństwo, szacunek dla przełożonych i współpracowników, miała również niemiecka etyka pracy oraz działalność i nauka Kościoła katolickiego. Szacunek pracy był ściśle powiązany ze sferą religijną, niedziela była wolna od pracy i dawała możliwości udziału w obrzędach religijnych, dawała zarazem możliwość spędzania czasu wolnego od pracy z rodziną. Istotne miejsce zajmowało wychowanie śląskiego robotnika dla przemysłu poprzez przenoszenie elementów dyscypliny pracy, porządku, systematyczności także poza miejsce pracy - do swojego domu. Ojcowie i dziadkowie byli tu głównymi, a niejednokrotnie jedynymi przekazicielami tradycji, wartości moralnych i obyczajowych. Powstała zarazem specyficzna więź

\footnotetext{
${ }^{18}$ U. Swadźba, Etos pracy na Górnym Ślasku. Tradycja, współczesne oblicze i zmiany, „Studia Socjologiczne” nr 4/2009 (195), s. 167.

${ }^{19}$ U. Swadźba, Geneza i ewolucja śląskiego etosu pracy, „Kultura i Społeczeństwo” nr 4, październik - grudzień 2002, s. 133-147.
} 
rodzinna związana $\mathrm{z}$ wykonywaniem pracy pokoleniowo często $\mathrm{w}$ tej samej kopalni czy hucie. Obowiązywał przekazywany z pokolenia na pokolenie ścisły podział ról, chłopców przygotowywano do zawodów robotniczych - do pracy w przemyśle (duży nacisk kładziony był na rozwój szkolnictwa - głównie zawodowego), natomiast dziewczęta do pracy w domu i wychowywania dzieci. Pogląd, że mężczyzna ma ciężką i solidną pracą zarobić na utrzymanie swojej rodziny, a kobieta ma zająć się prowadzeniem domu i wychowywaniem dzieci, był powszechnie akceptowalnym wzorcem życia śląskich rodzin. Wzorzec ten został przedstawiony m. in. w jednym z filmów śląskiego tryptyku Kazimierza Kutza „Sól ziemi czarnej”. Dzieło to, przedstawia wydawać by się mogło przerysowany obraz tamtych czasów, ale odnosi się do tego, co dla mieszkańców Śląska było ważne, czyli do pracy, rodziny, domu i kościoła. Fakt, że dom rodzinny jest miejscem, w którym przekazuje się następnym pokoleniom wartości i normy oraz wzorce zachowań dotyczące poszanowania dla ciężkiej fizycznej pracy i to stanowiło powód do dumy. „Na pracy jako wartości zbudowana została cała rygorystyczna etyka zawodowa, w której naczelne miejsce zajmowały: rzetelność, sumienność, szacunek dla kwalifikacji zawodowych, solidarność i poczucie odpowiedzialności za innych. Umiejętność współpracy i łatwość w nawiązywaniu kontaktów na płaszczyźnie zawodowej to cechy śląskiego robotnika"20. Szczególnego znaczenia nabierała praca, ta ciężka i niebezpieczna, związana z górnictwem czy hutnictwem, którą podejmowało większość mężczyzn zamieszkałych i zatrudnionych na Śląsku. Praca, często w skrajnie niebezpiecznych warunkach wpływała również na tworzenie odrębnych więzi emocjonalnych i cech psychicznych, które kształtowały „twardą” osobowość robotnika. „Tego rodzaju pracy, wykonywanej w grupie, zawsze towarzyszyło zagrożenie utratą życia bądź ciężkim kalectwem. Dlatego od solidarności zawodowej, ścisłego zachowania

${ }^{20}$ M. Błaszczyk-Wacławik, W. Błasiak, T. Nawrocki, Górny Ślask szczególny przypadek kulturowy, Wyd. Naukowe Jan Szumacher, Kielce 1990, s .13. 
norm bezpieczeństwa zależało życie własne i kolegów”21. Cały ten proces i wszystkie jego elementy ukształtowały wzorzec robotnika opanowanego, rzetelnego, wytrwałego, niezależnego, o dużym poczuciu godności, z szacunkiem dla wysokich kwalifikacji, aktywnego na płaszczyźnie spraw narodowych, na polu kulturalno-oświatowym, z dużym poszanowaniem tradycji i głęboko religijnego.

Po II wojnie światowej zasoby i potencjał Śląska miały znacząco wpłynąć na odbudowę naszego kraju. Zwiększano wydobycie węgla i produkcję stali, próbowano wykorzystać do tego „śląską pracowitość” pracy oraz propagandę komunistycznej ideologii poprzez między innymi dowartościowanie pracy robotnika. Wezwaniu do zwiększania norm i przekraczania planów nie towarzyszyło przestrzeganie norm bezpieczeństwa, które często były naginane do potrzeb zadania. Nie zważano na pracownika, liczyły się tylko wyniki za cenę zdrowia, a nawet życia pracowników. Jednocześnie tych, którzy nie chcieli zgadzać się na taki styl pracy, zmuszano szantażem. Postępowanie takie pozostawało w sprzeczności z wartościami i normami śląskiego szacunku dla pracy. Brak zgody na udział w komunistycznym wyścigu pracy wynikał również z głębokiej religijności. Śląski robotnik zawsze był związany z Kościołem, wykorzystywanie niedzieli jako dnia pracy kłóciło się z wyznawanymi wartościami. Zachwiano również dotychczasowy utarty zwyczaj przekazywania kwalifikacji zawodowych przez starych mistrzów młodym i stopniowego wdrażania do zawodu. Pomimo, iż owe czasy ideologizowały ciężką pracę fizyczną, to jednocześnie odrzuciły istotne dla robotników śląskich wartości dotyczące więzi rodzinnych, hierarchii zawodowej, uczciwości i gospodarności.

Kolejne lata zahamowały pęd bicia rekordów i podjęto starania mechanizacji pracy, postawiono również na postęp techniczny. Jednocześnie nastąpiło rozprężenie $\mathrm{w}$ dyscyplinie pracy, wzrost absencji, łamanie norm społecznych. Pomimo, iż ówczesne władze „dbały” o po-

${ }^{21}$ U. Swadźba, Geneza i ewolucja śląskiego etosu pracy, dz. cyt., s. 133-147. 
zytywny wizerunek ciężko pracującego robotnika, następowały zmiany $\mathrm{w}$ tradycyjnym systemie wartości. Okres ten przyniósł większy nacisk na aktywność partyjną niż zawodową, ci którzy chcieli awansować nie musieli być koniecznie kontynuatorami tradycyjnych wartości pracy, wystarczyło zapisać się do partii. Pomimo, iż takie postępowanie pozostawało w sprzeczności z tradycją i religijnością śląskich robotników, znajdowały się osoby, które wybierały taką drogę „kariery”. W tym też okresie na Śląsk napłynęła duża liczba osób, która nie znała tradycyjnego modelu śląskiego robotnika i nie charakteryzowała się kulturą pracy w przemyśle. W czasach realnego socjalizmu podjęto próbę „stworzenia nowej wartości” śląskiej pracy w przemyśle. Dotyczył on wprawdzie pracowitości, dyscypliny i posłuszeństwa, ale pozbawiony był dobrej organizacji pracy, gospodarności, poszanowania tradycji i powiązania z religią. W efekcie zaproponowano wzorce zachowań, które nie były spójne $\mathrm{z}$ dotychczasowym dobrze znanym systemem wartości. Nie potrafiono, czy też nie chciano wykorzystać wartości i norm „śląskiego etosu” pracy obowiązującego i przestrzeganego do tej pory przez niemal wszystkie pokolenia śląskich robotników. Pomimo silnego oddziaływania ideologii komunistycznej na sferę zawodową, nie potrafiła ona w równym stopniu oddziaływać na sferę prywatną śląskich rodzin, które pozostały, wbrew założeniom i oczekiwaniom, przekaźnikiem wszystkich wartości obejmujących także treści religijne, które $z$ taką determinacją były odrzucane przez komunistyczne władze. „Głównym przekaźnikiem etosu pracy zarówno w sferze pracy zawodowej, jaki i prywatnej była rodzina. Wartości i normy związanie z tradycją pracy fizycznej w najwyższym stopniu zostały zachowane w sferze prywatnej pracy w polu, domu i obejściu"22.

Śląski autorytet pracy przez wiele lat był poddawany najróżniejszym próbom, był wystawiany na oddziaływanie rozmaitych ideologii i propagandy, efektem tych działań miała być deprecjacja tradycji śląskich robotnika. Pomimo zmian w systemach wartości wiele z nich po-

${ }^{22}$ Tamże. 
zostało niezmiennych, możemy zaliczyć do nich: przestrzeganie przez górników obowiązkowego udziału w świątecznych obrzędach religijnych, posiadanie własnych symboli, strojów i rytuałów.

W okresie transformacji nastąpił istotny zwrot w wartościowaniu pracy - pojawił się dotąd nieznany „czynnik, który wpłynął zdecydowanie na śląski etos pracy, to bezrobocie. ... Z jednej strony praca jako dobro trudno dostępne jest wysoko wartościowana i ceni się sam fakt jej posiadania, z drugiej strony - niemożność jej wykonywania mimo posiadanych kwalifikacji powoduje deprecjację wartości. ... Takie ograniczenie nie było znane za czasów niemieckich i dlatego Ślązacy bardzo dotkliwie przeżywali swoje bezrobocie i starali się ukrywać jego skutki. Nawet praca bezrobotnych w „biedaszybach ” miała nie tylko wymiar materialny, ale również symboliczny - należało się do grupy pracujących i było się użytecznym w społeczeństwie"23. Pozostawanie bez pracy i brak możliwości jej uzyskania uświadomiło śląskim pracownikom, że praca może być dobrem niedostępnym dla wszystkich i należy o nią dbać. „Podważyło to śląski etos pracy jako coś niepotrzebnego i bezużytecznego" ${ }^{24}$. Zmiany gospodarcze spowodowały również zmniejszenie zapotrzebowania na pracę fizyczną, a zwiększyły popyt na pracę umysłową. Ta natomiast w większości była wykonywana przez osoby przyjezdne i nie była już tak dostępna dla mieszkańców Śląska (chociażby z uwagi na ich niższe wykształcenie - głównie zawodowe). Jednocześnie w tej sferze nie dochodziło do tak gwałtownych redukcji zatrudnienia. Kariera zawodowa młodych chłopców nie była już tak naturalna, nie była oczywista kontynuacja pokoleniowa zawodu, który po przodkach „miało się we krwi”, i z którym młody człowiek stykał się w domu rodzinnym od najmłodszych lat. Ubieganie się o pracę umysłową również nie było łatwe, najczęściej z powodu braku odpowiedniego wykształcenia oraz braku odpowiednich kwalifikacji. Wyjście poza krąg robot-

\footnotetext{
${ }^{23}$ Tamże.

${ }^{24}$ Tamże.
} 
niczy było dosyć trudne, ale nie niemożliwe, w szczególności u osób zdolnych i ambitnych. Tym samym śląski etos pracy ulegał rozszerzeniu o zawody odbiegające od zawodów związanych tylko $\mathrm{z}$ wykonywaniem pracy fizycznej, ale również pracy umysłowej wykonywanej przez kobiety. „Wzrost wykształcenia, większy popyt na rynku na pracę kobiecą spowodowały, że kobiety śląskie nie widzą się już w tradycyjnej roli pani domu"25.

Dla śląskich robotników najbardziej dotkliwym okazała się restrukturyzacja górnictwa. „Najwięcej emocji wzbudził wprowadzony w listopadzie 1998 roku Górniczy Pakiet Socjalny. Górnikom zaproponowano wówczas jednorazową odprawę - po 50 tys. zł brutto („na rękę” 37 tys. zł). Otrzymywanie takiej odprawy obwarowane było kilkoma zasadami, wśród których najważniejsza stanowiła o tym, że osoba pobierająca świadczenie nie może być już zatrudniona w kopalni. Odprawy miały stworzyć pracownikom nowe możliwości znalezienia pracy, przekwalifikowania się, założenia własnej firmy. W latach 1998-2001 skorzystało z nich prawie 37 tys. górników. Wielu z nich nie potrafiło jednak efektywnie spożytkować otrzymanych środków pieniężnych, przeznaczającje często na zakup nowego samochodu, remontu mieszkań, czy wycieczki zagraniczne"26. Bardzo często osoby, które spożytkowały odprawy niezgodnie z przeznaczeniem, stały się klientami pomocy społecznej z powodu braku środków pieniężnych na zapewnienie potrzeb rodziny. Nie znaczy to, że klientami pomocy społecznej na Śląsku są jedynie bezrobotni górnicy. Jednakże bezrobocie jest jednym z najczęściej wymienianych powodów (dysfunkcji) przyznania świadczeń z pomocy społecznej.

Tradycyjny charyzmat pracy przez dziesięciolecia kształtował całe pokolenia śląskich robotników, opierał się na wartości pracy fizycznej,

${ }^{25}$ Tamze, s. 186.

${ }^{26}$ D. Czubala, M. Miczka-Pajestka, „Tradycja i współczesność. Folklor - Język Kultura”. Oświata i kultura na Podbeskidziu, t. V, Wyd. ATH, Bielsko-Biała 2009, s. 375. 
która stanowiła o wartości człowieka. Tradycja ta ulegała jednak stopniowym zmianom. Rozmaite oddziaływania z jednej strony modyfikowały, a z drugiej utrwalały niektóre jej elementy. Destrukcyjny wpływ miała ideologia czasów realnego socjalizmu - pochwale dla ciężkiej pracy robotnika nie towarzyszył ważny dla śląskiego robotnika aspekt religijny, poszanowania dla odpoczynku od pracy, sumienności, dyscypliny i dobrej organizacji pracy. $\mathrm{Na}$ etos pracy wpływ miała również zmiana struktury śląskiego rynku pracy. Restrukturyzacja w przemyśle spowodowała znaczne przemieszczenia siły roboczej powodując jej nadwyżki wśród reprezentantów niektórych zawodów i deficyty w innych obszarach. Ujawniło się również, nieznane do tej pory dla śląskiego robotnika, bezrobocie. Na cechy tradycyjnego chryzmatu pracy wpływ miała również ludność napływowa o odmiennej kulturze i braku doświadczenia w pracy w przemyśle, prezentująca odmienne postawy. „W stereotypowym postrzeganiu Śląska miejsce pracy zawodowej młodego mężczyzny było w hucie czy kopalni. Nie zawsze była to prawda, ponieważ od okresu realnego socjalizmu synowie górników nie chcieli kontynuować rodzinnej tradycji. Coraz popularniejsze było uzyskiwanie solidnego technicznego wykształcenia i podejmowanie pracy w innych miejscach niż górnictwo czy hutnictwo"27.

Rozważania dotyczące znaczenia śląskiego charyzmatu pracy w odniesieniu do współczesności możemy rozpatrywać przez pryzmat transformacji systemowej, czasy przemian społeczno - gospodarczych i zmian w strukturze rynku pracy. Praca nadal stanowi istotną wartość, jest nią ze względów materialno-bytowych, stanowi przyczynek do rozwoju człowieka. Jego ewolucja związana jest z przemianami w sferze świadomości, jak i układu wartości obecnego pokolenia. Dla mieszkańców regionu praca stanowiła największą wartość, była tak naturalnym i niezbywalnym prawem, że nie do wyobrażenia było nie pracować.

${ }^{27}$ U. Swadźba, Etos pracy na Górnym Śląsku, dz. cyt., s.181. 
Obecny pogląd na tradycyjny model pracy i jej znaczenie w życiu zostanie przedstawione w oparciu o badanie przeprowadzone wśród osób korzystających ze świadczeń z pomocy społecznej. Badania zostały przeprowadzone w Ośrodku Pomocy Społecznej w Gliwicach, Pyskowicach, Rudzie Śląskiej i Zabrzu w marcu i kwietniu 2019 roku pośród 53 osób. Sformułowane pytania miały na celu pozyskanie informacji dotyczących pracy jako jednej z istotnych wartości w życiu mieszkańców regionu. Jednocześnie badana grupa to przedstawiciele regionu, którzy nie są aktywni zawodowo.

Praca jako wartość i ważny element w życiu (\%). Badania i obliczenia własne

\begin{tabular}{|c|c|c|c|c|}
\hline Lp. & & TAK & NIE & NIE WIEM \\
\hline 1 & $\begin{array}{l}\text { Czy Pan/Pani uważa, że tradycyjny Śląski model, } \\
\text { kiedy to mężczyzna pracuje zawodowo i zarabia } \\
\text { na utrzymanie rodziny, a kobieta prowadzi dom } \\
\text { i zajmuje się wychowaniem dzieci jest jeszcze } \\
\text { obowiązujący? }\end{array}$ & 28,30 & 54,72 & 16,98 \\
\hline 2 & $\begin{array}{l}\text { Zawody odbiegające od zawodów związanych } \\
\text { tylko z wykonywaniem pracy fizycznej. }\end{array}$ & 60,38 & 24,53 & 15,09 \\
\hline 3 & $\begin{array}{l}\text { Czy uważa Pana/Pani, że większą wartość ma } \\
\text { praca fizyczna niż umysłowa? }\end{array}$ & 20,75 & 66,04 & 13.21 \\
\hline 4 & $\begin{array}{l}\text { Czy uważa Pan/Pani, że do tego, aby człowiek } \\
\text { mógł się rozwijać jest potrzebna praca? }\end{array}$ & 64,15 & 18,87 & 16,98 \\
\hline 5 & $\begin{array}{l}\text { Czy Pana/Pani zdaniem osoby, które mogą pra- } \\
\text { cować, a nie pracują powinny robić wszystko } \\
\text { żeby pracę znaleźć? }\end{array}$ & 77,36 & 7,55 & 15,09 \\
\hline 6 & $\begin{array}{l}\text { Czy uważa Pana/Pani, że w pracy należy być za- } \\
\text { wsze uczciwym i solidnym? }\end{array}$ & 92,46 & 3,77 & 3,77 \\
\hline 7 & $\begin{array}{l}\text { Czy Pana/Pani zdaniem należy pracować, nawet } \\
\text { jeżeli za jej wykonywanie otrzymuje się za niskie } \\
\text { wynagrodzenie? }\end{array}$ & 54,72 & 23,68 & 13,20 \\
\hline 8 & $\begin{array}{l}\text { Czy Pana/Pani zadaniem osobom, które dłuższy } \\
\text { czas nie pracowały trudniej jest znaleźć pracę? }\end{array}$ & 96,23 & 0,0 & 3,77 \\
\hline 9 & Czy obecnie Pan/Pani pracuje zawodowo? & 26.42 & 73,58 & $\mathbf{X X}$ \\
\hline 11 & $\begin{array}{l}\text { Czy dla Pana/Pani praca jest jedną z najważniej- } \\
\text { szych wartości? }\end{array}$ & 69,81 & 30,19 & $\mathbf{X X}$ \\
\hline
\end{tabular}




\begin{tabular}{|c|l|c|c|c|}
\hline 12 & $\begin{array}{l}\text { Czy korzysta Pan/Pani ze świadczeń pomocy } \\
\text { społecznej? }\end{array}$ & $\mathbf{8 3 , 0 2}$ & $\mathbf{1 6 , 9 8}$ & $\mathbf{X X}$ \\
\hline 13 & $\begin{array}{l}\text { Gdyby była możliwość otrzymywania środków } \\
\text { w takiej samej wysokości jak wynagrodzenie za } \\
\text { pracę i jednocześnie nie trzeba byłoby pracować } \\
\text { to, czy skorzystał/a by Pan/Pani z takiego rozwią- } \\
\text { zania? }\end{array}$ & $\mathbf{5 4 , 7 2}$ & $\mathbf{4 5 , 2 8}$ \\
\hline $\begin{array}{l}\text { Czy w Pana/Pani opinii otrzymywanie pieniędzy } \\
\text { „za nic" (np. zasiłki dla bezrobotnych) może po- } \\
\text { wodować rozleniwienie i niechęć do poszukiwa- } \\
\text { na i podjęcia stałej pracy? }\end{array}$ & $\mathbf{5 8 , 4 9}$ & $\mathbf{4 1 , 5 1}$ & $\mathbf{X X}$ \\
\hline
\end{tabular}

\begin{tabular}{|l|l|c|}
\hline & Obecnie nie pracuję zawodowo ponieważ & $\mathbf{0 , 0}$ \\
\hline \multirow{2}{*}{10 a)chcę prowadzić własną działalność gospodarczą } & $\mathbf{1 2 , 8 5}$ \\
\hline $\begin{array}{l}\text { b) szukam pracy wyłącznie zgodnej z moimi kwalifikacjami } \\
\text { i oczekiwaniami }\end{array}$ & $\mathbf{5 3 , 8 5}$ \\
\hline \begin{tabular}{l|} 
c) nie otrzymałem/am żadnej oferty pracy, \\
\cline { 2 - 3 } d) nie szukam pracy,
\end{tabular} & $\mathbf{1 7 , 9 5}$ \\
\hline $\begin{array}{l}\text { e) inny powód, proszę podać jaki: } \\
\text { - } 4 \text { osoby - stan zdrowia } \\
-2 \text { osoby - wiek }\end{array}$ & $\mathbf{1 5 , 3 8}$ \\
\hline
\end{tabular}

\begin{tabular}{|l|l|r|}
\hline 15 & $\begin{array}{l}\text { Proszę dokończyć zdanie: } \\
\text { Praca zawodowa jest dla mnie: }\end{array}$ & $\begin{array}{r}36 \text { osób - brak odpowiedzi } \\
17 \text { osób - dokończyło zdanie. }\end{array}$ \\
\hline
\end{tabular}

- koniecznością,

- obowiązkiem,

- satysfakcją,

- podstawą egzystencji,

- możliwością usamodzielnienia,

- zapewnieniem godnego życia,

- dobrym sposobem na wyjście z domu,

- dążeniem do rozwijania swoich umiejętności i kwalifikacji,

- poczuciem bezpieczeństwa oraz dążeniem do celu,

- formą zarabiania na życie możliwością rozwoju nabierania doświadczenia i możli-

wością kontaktu z ludźmi,

- naturalnym prawem, środkiem do utrzymania rodziny 
Postawione pytania zostały podzielone na trzy umowne grupy zagadnień.

Pierwsza część to pytania dotyczące modelu pracy, jej ważności i określenia priorytetów pracy w życiu: P 1 do P 4, P 6, P 7, P 11.

Odpowiadając na P 1 - Czy Pan/Pani uważa, że tradycyjny Śląski model, kiedy to mężczyzna pracuje zawodowo i zarabia na utrzymanie rodziny, a kobieta prowadzi dom i zajmuje się wychowaniem dzieci, jest jeszcze obowiązujący: przeszło połowa badanych, czyli 54\% wskazała, że wskazany model już nie obowiązuje, przy czym $28 \%$ jest zdania, że nadal obowiązuje. Na P 2 - Czy w Pana/Pani opinii praca jest nadal jedną z najważniejszych wartości dla mieszkańców Śląska: większość badanych tj. 60\% wskazała, że jest jedną z najważniejszych wartości oraz P 4 - Czy uważa Pan/Pani, że do tego, aby człowiek mógł się rozwijać jest potrzebna praca: $65 \%$ wskazała, że jest potrzebna. Jednocześnie na P 3 - Czy uważa Pana/Pani, że większą wartość ma praca fizyczna niż umysłowa: $66 \%$ badanych wskazała, że praca fizyczna nie ma większej wartości od pracy umysłowej. Odpowiadając na P 6 - Czy uważa Pana/ Pani, że w pracy należy być zawsze uczciwym i solidnym: 92\% uważa, że w pracy należy zawsze być uczciwym i solidnym. Jednocześnie $54 \%$ uważa, że należy pracować pomimo otrzymywania niskiego wynagrodzenia P 7 - Czy Pana/Pani zdaniem należy pracować, nawet jeżeli za jej wykonywanie otrzymuje się za niskie wynagrodzenie. Dla prawie $70 \%$ badanych praca jest jedną z najważniejszych wartości P 11 - Czy dla Pana/Pani praca jest jedną z najważniejszych wartości.

Druga część to określenie obecnej sytuacji zawodowej i podejmowana aktywności w celu jej uzyskania w przypadku osób bezrobotnych: P 5, P 8 do P 10.

Udzielając odpowiedzi na P 5 - Czy Pana/Pani zdaniem osoby, które mogą pracować, a nie pracują, powinny robić wszystko żeby pracę znaleźć: $77 \%$ badanych podkreśliło, iż osoby, które nie pracują powinny robić wszystko, aby znaleźć pracę. Jednocześnie P 8 - Czy Pana/Pani 
zadaniem osobom, które dłuższy czas nie pracowały, trudniej jest znaleźć pracę? 96\% wskazuje na tę trudność. Badana grupa, to jednocześnie prawie 73\% osób pozostających obecnie bez pracy P 9 - Czy obecnie Pan/Pani pracuje zawodowo, jako powód takiej sytuacji? P 10 - Obecnie nie pracuję zawodowo ponieważ: 12\% szuka pracy zgodnej z kwalifikacjami i oczekiwaniami, 53\% wskazało, że nie otrzymało żadnej oferty pracy (może to wskazywać na ich bierną postawę), 17\% nie szuka żadnej pracy, jednocześnie 15\% podało inny powód: stan zdrowia oraz wiek. Nikt $\mathrm{z}$ badanych nie zadeklarował chęci prowadzenia własnej działalności gospodarczej.

Trzecia część to pytania dotyczące korzystania ze świadczeń i możliwości otrzymywania świadczeń „bez wysiłku”: P 12 do 15. Badana grupa to przeszło $83 \%$ osób korzystających ze świadczeń pomocy społecznej P 12 - Czy korzysta Pan/Pani ze świadczeń pomocy społecznej. Przeszło połowa $54 \%$ osób zdecydowałoby się na pozostanie $\mathrm{w}$ domu i otrzymywanie środków w wysokości wynagrodzenia bez konieczności pracy. P 13 - Gdyby była możliwość otrzymywania środków w takiej samej wysokości jak wynagrodzenie za pracę i jednocześnie nie trzeba byłoby pracować to, czy skorzystał/a by Pan/Pani z takiego rozwiązania? Tym samym prawie $60 \%$ badanych wskazało, że otrzymywanie pieniędzy „za nic” może powodować stagnację $\mathrm{w}$ aktywności poszukiwania i podjęcia pracy. P 14 - Czy w Pana/Pani opinii otrzymywanie pieniędzy „za nic” (np. zasiłki dla bezrobotnych) może powodować rozleniwienie i niechęć do poszukiwana i podjęcia stałej pracy. Na P 15 - Proszę dokończyć zdanie: Praca zawodowa jest dla mnie... - prawie 68\% nie wykonało wskazanego zadania, natomiast 32\% dokończyło zdanie. Oto, moim zdaniem, kilka ciekawych i intrygujących wypowiedzi:

- dobrym sposobem na wyjście z domu,

- dążeniem do rozwijania swoich umiejętności i kwalifikacji,

- poczuciem bezpieczeństwa oraz dążeniem do celu, 
- formą zarabiania na życie możliwością rozwoju nabierania doświadczenia i możliwością kontaktu z ludźmi,

- naturalnym prawem, środkiem do utrzymania rodzin.

Wśród badanych większość to kobiety, które stanowią 73\%, jednocześnie respondenci to osoby $\mathrm{z}$ wykształceniem podstawowym i zawodowym w przedziale wiekowym pomiędzy 31 a 50 rokiem życia, które pracowały najczęściej w przedziale od 1 roku do 20 lat. Wśród badanej grupy 14 osób nadal pracuje, jednocześnie wśród wszystkich badanych 13 osób do tej pory nie pracowało.

Praca z osobami, które korzystają ze świadczeń pomocy społecznej nie jest łatwym zadaniem i stanowi wyzwanie dla pracy socjalnej. „Klienci pomocy społecznej nie składają się z przeciętnych mieszkańców, obywateli, ludzi, ... Ich życie niekiedy znacznie różni się od życia statystycznego obywatela..."28.

Programując pracę socjalną można, a wręcz należy odnieść się do różnych dziedzin nauki, do ogólnie akceptowalnych i respektowanych norm i wartości, co może przyczynić się do efektywniejszej pracy. Czy odwoływanie się do wartości jako normy może spowodować dążenie do jej respektowania? Jeszcze do niedawna nadrzędną wartością dla mieszkańców Śląska była ciężka praca fizyczna. Odnoszenie się w dzisiejszych czasach do nieobowiązujących już modeli i wartości pracy, nie znajduje jednoznacznego uzasadnienia. Nie oznacza to jednak, że należy zapomnieć o tradycji, która była tak mocno zakorzeniona, a zapewne jeszcze jest kultywowana w niektórych środowiskach zawodowych. „Wartość jest tym, co w sposób najbardziej pełny umożliwia rozwijanie tych zdolności. Czyni także życie człowieka pełnym, daje mu nie tylko poczucie, ale i również niedostępne w inny sposób spełnienie" ${ }^{29}$. Człowiek może

${ }^{28}$ M. Granosik, Profesjonalny wymiar pracy socjalnej, „Śląsk” sp. z o.o. Wydawnictwo Naukowe, Katowice 2006, s. 155.

${ }^{29}$ G. Grzybek, Praca socjalna w założeniach „etyki rozwoju”, dz. cyt., s. 70. 
być szczęśliwym i spełnionym wykonując pracę, przede wszystkim tę, która przedstawia wartość w indywidualnym wymiarze gospodarczym, społecznym i kulturowym.

Do badań zostali wybrani klienci pomocy społecznej, to szczególna grupa, w której większość stanowią osoby pozostające bez pracy od wielu lat. Tym samym dążenie do podjęcia pracy zarobkowej winna stanowić dla nich szczególną wartość i miejsce w życiu. Większość badanych osób wskazała, że praca zarówno dla mieszkańców Śląska, jak i dla nich samych stanowi jedną z najważniejszych wartości. Uważają przy tym, że osoby bezrobotne powinny podejmować wszelkie możliwe działania, aby pracę znaleźć. Jednocześnie większość osób badanych, która pozostaje bez pracy, jako główny powód jej braku wskazuje na to, że „nie otrzymali żadnej oferty pracy”, a część z nich przyznaje, że „nie szuka pracy”. Trudno w takiej sytuacji odnieść się do tradycyjnych śląskich wartości i charyzmatu pracy. Do niedawna jeszcze brak pracy był pojęciem wysoce nierealistycznym. Przyjęte $z$ domu rodzinnego wartości nie obejmowały pojęcia braku pracy, czyli czymś co... „czyni także życie człowieka pełnym, daje mu nie tylko poczucie, ale i również niedostępne w inny sposób spełnienie. Zatem realizacja wartości wiąże się ze szczęściem"30. To sami respondenci wskazali, że aby człowiek mógł się rozwijać potrzebna jest praca, która daje możliwość uzyskania środków na utrzymanie rodziny, możliwość rozwoju, kontaktu z innymi ludźmi, poczucie bezpieczeństwa. Brak pracy zaburza równowagę materialno-emocjonalną osoby pozostającej bez pracy, jak i jej najbliższego otoczenia.

Bezrobocie w naszym kraju występuje globalnie, nie ma bowiem regionu, w którym by nie występowało, jest zarazem zjawiskiem podlegającym nieustannym zmianom. Dla mieszkańców Śląska brak pracy wydaje się być szczególnie trudnym aspektem obecnej rzeczywistości. Z perspektywy pracy pracownika socjalnego osoby bezrobotne stano-

${ }^{30}$ Tamże. 
wią szczególne wyzwanie dla pracy socjalnej. Odniesienie się do tradycji pracy śląskiego robotnika jest praktycznie niemożliwe. Wartość pracy podlega takim przekształceniom, że już tylko nieliczni kontynuatorzy pozostają wierni pokoleniowej tradycji. Zmiany gospodarcze spowodowały, że obszar Śląska nie jest już kojarzony, jako okręg wyłącznie przemysłowy. Dziedziczenie zawodu z ojca na syna przestało być tak oczywiste i atrakcyjne, praca fizyczna utraciła swoją dotychczasową wartość, a do wykonywania pracy umysłowej należało legitymować się wyższym niż tylko zawodowym poziomym wykształcenia. Trudności, które zaburzały swobodne poruszanie się po rynku pracy wniosły istotnie zmiany w systemach wartości, te natomiast przeformułowały aktywność zawodową w bierne wyczekiwania na aktywność pracowników instytucji pomocowych i zastępcze podejmowanie działań umożliwiających powrót na rynek pracy. Tym samym bezrobocie stało się udziałem części mieszkańców Śląska z jednoczesnym brakiem aktywności zmierzającej do znalezienia zatrudnienia, liczą głównie na interwencję instytucji. Jednakże oczekiwanie na to, co przyniesie los pozostawało (i pozostaje pośród części mieszkańców regionu) w sprzeczności ze śląskim etosem pracy i nie mieściło się w pojmowaniu rzeczywistości. Nie można było nie pracować.

Realizując pracę społeczną trudno jest odnosić się do systemów, które nie stanowią źródła energii oraz motywatora do codziennych zmagań. Podstawą procesu wsparcia, jak i udzielenia pomocy jest założenie maksymalnej aktywności ze strony osoby zainteresowanej przy jej współpracy z pracownikiem socjalnym. Aby znaleźć pracę nie można biernie czekać, na to, co przyniesie los lub co zrobią za nas inni. Praca nie zapuka do naszych drzwi. Czas działa na niekorzyść, im dłużej pozostaje się bez pracy, tym trudniej ponownie powrócić do zatrudnienia. Można utracić posiadane kwalifikacje, bezczynność zawodowa odzwyczaja od rytmu pracy, a długotrwałe pozostawanie w sytuacji stresowej prowadzić może do wyobcowania i osamotnienia. 
Opierając się zatem na przeprowadzonych badaniach i na wieloletnim doświadczeniu pracownika socjalnego, można zaproponować następujące stwierdzenia:

> część osób bezrobotnych, która korzysta z pomocy społecznej nie przejawia większego zainteresowania w poszukiwaniu i podjęciu zatrudnienia, prawie $54 \%$ badanych wskazało, że nie pracuje ponieważ nie otrzymało oferty pracy, aż $18 \%$ przyznaje otwarcie, że jej w ogóle nie szuka. Do takiego postępowania przyczyniła się zmiana systemów wartości, odejście od tradycyjnego śląskiego modelu pracy oraz czynniki zewnętrzne, takie jak trudności w uzyskaniu pracy oraz zmiana oczekiwań pracodawców,

> czas pozostawania bez pracy negatywnie wpływa na jej ponowne znalezienie, klienci pomocy społecznej często pozostają od wielu lat bez pracy (5 - 15 lat), utracili nawyk pracy, często w kontaktach z pracownikiem socjalnym podejmują aktywność, aby pracy nie podjąć, nawet w formie prac społeczno- użytecznych,

> pomimo wskazania, że praca stanowi jedną z największych wartości, jest potrzebna aby się rozwijać i należy pracować nawet jeżeli wynagrodzenie za pracę jest za niskie i robić wszystko aby pracę znaleźć, nie przekładają tych wartości na własną aktywność,

> wieloletnie korzystanie ze wsparcia finansowego państwa, które udzielane jest przez instytucje pomocowe, prowadzi często do uzależnienia od systemu pomocy - otrzymywanie pieniędzy „Za nic” rozleniwia, powoduje niechęć do poszukiwania i podjęcia zatrudnienia, na co wskazuje większość (59\%) badanych.

> łączna wysokość świadczeń, jaką otrzymuje rodzina, często przekracza wysokość wynagrodzenia (zdarza się, że przekracza wysokość wynagrodzenie pracownika socjalnego w danym ośrodku).

Śląsk, jego mieszkańcy, wartości, normy i obyczaje ulegają ciągłym zmianom. Przemiany społeczno-gospodarcze sprawiły, że region 
kojarzony do tej pory z przemysłem ciężkim i wydobywczym, utracił swój prymat, za przyczyną m.in. restrukturyzacji całego przemysłu i związanego z tym zamykania kolejnych przedsiębiorstw: kopalń, hut, zakładów przemysłu ciężkiego. Jednoczesne zmiany w strukturze zatrudnienia doprowadziły do przesunięcia siły roboczej i zmniejszenia zapotrzebowania na pracę fizyczną w poczet pracy umysłowej. Klasyczny model pracy, pielęgnowany i kultywowany przez wiele lat oddziaływał na mieszkańców Śląska, jego istota opierała się na wykonywaniu ciężkiej fizycznej pracy, która jedynie stanowiła o wartości człowieka. Wraz ze zmniejszeniem znaczenia pracy fizycznej nastąpiło przeformułowanie w hierarchii wartości pracy, nastąpiła degradacja znaczenia - autorytetu pracy jako jednej z najważniejszych i tradycyjnych wartości. Zwyczaj, że mężczyzna pracuje i zarabia na utrzymanie rodziny, a kobieta zajmuje się domem i wychowywaniem dzieci jest już nieaktualny. Wykonywanie pracy fizycznej utraciło swój tradycyjny charakter, pokoleniowe przekazywanie i dziedziczenie zawodu nie ma już takiego znaczenia, nie jest tak wysoce kultywowane i nie stanowi powodu do dumy dla młodego pokolenia - praca na kopalni czy w hucie nie jest już szczytem marzeń i możliwości. Bezrobocie spowodowało, iż część osób zdolnych do pracy i chcących pracować nie może pracy znaleźć, tym samym nie dysponuje własnymi środkami pieniężnymi na utrzymanie. Konieczność uzyskania środków finansowych spowodowało poszukiwanie rozmaitych możliwości ich zdobycia. Jedną z nich było zwrócenie się do ośrodka pomocy społecznej o wsparcie finansowe. Wypłacanie zasiłków bez konieczności wykonywania jakiejkolwiek pracy, przy spełnieniu jedynie wymogów formalnych pomocy społecznej spowodowało otrzymywanie pieniędzy „za nic”. Aby uzyskać pieniądze nie trzeba na nie zapracować. Możliwość uzyskiwania środków finansowych nie tylko w postaci wynagrodzenia za pracę, ale w formie zasiłków, spowodowała powstanie grupy korzystającej z takiej formy otrzymywania środków i uczyniła z tego sposób 
na życie. Osoby bezrobotne od wielu lat, które nie szukają zatrudnienia, spowodowały pojawienie się nowego trendu polegającego na pokoleniowym przekazywaniu nowej tradycji, czyli na korzystaniu ze świadczeń pomocy społecznej (nazwanej w literaturze „wyuczoną bezradnością”), w zamian za przekazywanie (dziedziczenie) zawodu, czy też pracy jako najważniejszej wartości w życiu. Takie postawy pozostają w sprzeczności z tradycyjnym śląskim charyzmatem i etosem pracy, który utracił siłę swojego oddziaływania na mieszkańców regionu. W pracy z bezrobotnymi klientami ośrodków pomocy społecznej, odnoszenie się do śląskiej tradycji pracowitości, rzetelności, gospodarności nie przynosi zamierzonego efektu. Coraz częściej w miejsce przekazywania „śląskiej pracowitości” pojawia się przekazywanie bezradności i bezczynności. Jak opierać się na tradycyjnym etosie, który uległ na tyle silnym przeobrażeniom, że dziś nie stanowi dla młodego pokolenia najważniejszej wartości. Zmianie ulega nie tylko samo znaczenie pracy jako najważniejszej wartości, ale również jej ekonomiczny i społeczny wymiar.

Praca decyduje o podstawie egzystencji, daje możliwość rozwoju i jest niezbywalnym prawem każdego człowieka. Niektórzy świadomie rezygnują z tego prawa. Dlaczego? To temat na inne rozważania.

\section{BIBLIOGRAFIA}

Adamski F., Wychowanie na rozdrożu: personalistyczna filozofia wychowania. Wydawnictwo Uniwersytetu Jagiellońskiego Kraków 1999.

Błaszczyk-Wacławik M., Błasiak W., Nawrocki T., Górny Śląsk szczególny przypadek kulturowy, Wydawnictwo Naukowe Jan Szumacher, Kielce 1990.

Chałas K., Wychowanie ku wartościom. Elementy teorii i praktyki. Godność, wolność, odpowiedzialność, tolerancja, t. 1, Wydawnictwo JEDNOŚĆ, Lublin-Kielce 2003. 
Czubala D., Miczka-Pajestka M. (red), Tradycja i współczesność. Folklor - Ję$z y k$ - Kultura, „Oświata i kultura na Podbeskidziu”, t. V, Wydawnictwo Akademii Techniczno-Humanistycznej, Bielsko-Biała 2009.

Drzewiecki M., Wychowanie w dobie ponowoczesności, Wydawnictwo JEDNOŚĆ, Kielce 2002.

Furmanek W., Człowiek, człowieczeństwo, wychowanie, Wydawnictwo Uniwersytetu Rzeszowskiego, Rzeszów 1995.

Granosik M., Profesjonalny wymiar pracy socjalnej, Wydawnictwo Naukowe „Śląsk” sp. z o.o., Katowice 2006.

Grzybek G., Etyka rozwoju a wychowanie, Wydawnictwo Uniwersytetu Rzeszowskiego, Rzeszów 2010.

Grzybek G., Praca socjalna w założeniach „etyki rozwoju”, [w:] Stala J. (red), Przestrzenie pracy socjalnej, Wydawnictwo Biblos, Tarnów 2010.

Jan Paweł II, Aby wychowanek nauczył się „być, a nie tylko „wiedzieć”, [w:] Rodzina w nauczaniu Jana Pawła II. Antologia wypowiedzi, (red.) J. Żukowicz, Kraków 1990, s. 187-202.

Okoń W., Nowy słownik pedagogiczny, Wydawnictwo Akademickie Żak, Warszawa 2007.

Sobolowa W., Tausz K., Badanie losów i postaw absolwentów śląskich ponadpodstawowych szkół zawodowych, „Polityka Społeczna” nr 1, styczeń 2002. s. 16-21.

Stępień A., Wstęp do filozofii, Wydawnictwo Towarzystwo Naukowe katolickiego Uniwersytetu Lubelskiego. Lublin 2001.

Stala J. (red), Przestrzenie pracy socjalnej, Wydawnictwo Biblos, Tarnów 2010.

Styczeń T., Antropologia Karola Wojtyły, [w:] „Osoba i czyn oraz inne studia antropologiczne, seria: Człowiek i Moralność. t. 4, (red.) T. Styczeń, W. Chudy, Lublin 2000.

Swadźba U., Etos pracy na Górnym Śląsku. Tradycja, współczesne oblicze i zmiany. „Studia Socjologiczne” nr 4/2009 (195), s. 167-190. 
Wartość pracy zawodowej...

Swadźba U., Geneza i ewolucja śląskiego etosu pracy, „Kultura i Społeczeństwo” nr 4, październik-grudzień 2002, s. 133-147.

Szołtysek A., Filozofia pedagogiki. Podstawy edukacji: teoria - metodyka - praktyka, Wydawnictwo IMPULS, Katowice 2003.

Tatarkiewicz W., Paregra, Państwowe Wydawnictwo Naukowe, Warszawa 1978. 